\title{
10. Climate change advocacy in the Pacific The role of information and communication technologies
}

\begin{abstract}
This article explores the phenomenon of the use of ICT for climate change activism in the Pacific. Climate change activism in the Pacific is characterised by the use of ICT tools such as social media. The article draws on semi-structured interviews and an analysis of social media sites to examine the use of social media in Pacific climate change campaigns. While other campaigns such as relating to West Papua have also been facilitated by social media, it has been generally NGO, citizen-led and varied in Pacific government support. In contrast, climate change campaigns in the Pacific are fully supported at the NGO, citizen, and state levels. Furthermore, while early Pacific ICT-based climate change campaigns used iconic images of Pacific Islanders leaving their homelands, more recent campaigns have leveraged social media to depict Pacific Islanders not as victims but as 'warriors'. This new imagery aims to empower Pacific Islanders and engender a regional Pacific identity that shows strength and solidarity on the Pacific's stance towards climate change.
\end{abstract}

Keywords: citizen journalism, climate change, COP21, Fiji, grassroots regionalism, ICTs, MOOCs, online activism, social media

\section{JASON TITIFANUE, ROMITESH KANT, GLEN FINAU and JOPE TARAI University of the South Pacific, Fiji}

\section{Introduction}

ACIFIC ISLAND nations currently face many socio-economic and environmental challenges (Robie, 2014a). Climate change has been identified as one of the critical challenges of this century. Being dominated by the vast Pacific Ocean, the Pacific Islands are particularly susceptible to climate change. Rises in sea level and changes in climatic conditions have meant that Pacific Islands face many threats. These include; coastal inundation and the submergence of low lying islands, increased salinisation of water sources and changes in the distribution of biodiversity potentially threatening food security and economic prosperity (Keener, Marra, Finucane, Spooner, \& Smith, 2013). 
Coupled with fragile economic structures, climate change has proven to be a formidable undertaking for Pacific leaders and communities.

Climate change and its causes is a problem of global proportions. The causes of climate change lie beyond the Pacific and disproportionately impact on Pacific Islanders who face inundation in their lifetimes. This poses particular problems for Pacific activists as they strive to educate and raise awareness on climate change. Pacific climate activism refers to the ever increasing numbers of individuals, groups and organisations in the Pacific working on climate change related issues. These groups focus on the various multi-faceted dimensions of climate change activism. This ranges along the spectrum of devising and implementing climate mitigation strategies at the community level, lobbying policy makers and increasing the level of climate change awareness amongst the general public. Lobbying by Pacific Islanders at the international scale is thus vital in addressing this issue. ICTs have great potential to assist in the dissemination of climate change information and in the mobilisation and coordination of people for the purpose of climate change advocacy.

In the Pacific, ICT tools and platforms such as social media have grown in their popularity and outreach (Finau et al., 2014; Singh, 2017). Improvements in technology have facilitated an exponential increase in accessibility to ICTs around the world. World Bank (2014) statistics for the Pacific indicate that access to ICTs is increasing at an exponential rate. With these increases, the potential of ICTs to be used as a means of reaching out to people and fostering climate change awareness and activism, also increases. With the limited resources available, Pacific Island governments, organisations and individuals have striven to disseminate information and mobilise interest in climate change. Over time, ICTs have come to play a prominent role as a means by which individuals, groups and organisations can spread messages, gain the interest of the populace and organise movements and activities centred on climate change activism. ICTs also have potential to act as a catalyst for the rebirth of grassroots regionalism. In essence, there have been points in Pacific history where widespread interest at the grassroots level on a particular issue has led to a bottom-up push that advocates for action on issues of regional interest (George, 2011). This is evidenced in the Free West Papua campaign. In this case, ICT tools were employed to garner interest throughout the region in the issue of West Papua (Robie, 2017). Through ICT tools such as social media, activists from around the Pacific region communicated and organised to articulate messages of protest against human rights violations in West Papua (Titifanue, Tarai, Kant \& Finau, 2016). Thus, the exponential growth rates of ICTs in the Pacific region have emplaced ICTs and their related platforms as being important means of diffusing news.

This exploratory research scrutinises the situation in the Pacific and the contemporary phenomenon of ICTs and how ICT tools have been utilised for 
disseminating and articulating messages on climate change, and bringing about behavioural change. The article examines how ICT platforms such as social media have been adapted by individuals and groups for use in climate change activism. The roles that ICTs have in the potential rebirth of grassroots regionalism is also examined.

\section{Climate change in the Pacific context}

Climate change in the context of this article refers to human induced climate change that has been caused by greenhouse gas emissions. Such changes in climate have resulted in changing weather patterns around the world. Extreme weather events have increased in frequency with countries recording unprecedented levels of extreme precipitation and/or heat (Adger, Huq, Brown, Conway, \& Hulme, 2003). The mean global temperature has also risen. This has resulted in the melting of polar ice caps and rising sea levels. This is further exacerbated by the fact that increasing temperatures cause water to expand thus resulting in the thermal expansion of oceans (Beaumont et al., 2014).

The islands of the Pacific region include many coral atolls and raised limestone islands. These islands have very low elevation above mean sea level. This low elevation means that a mere rise of several centimetres in sea level can potentially inundate entire islands. In small island states such as Kiribati, entire communities have been forced to relocate due to rising sea levels inundating their homes (Hall, 2015). In the case of island nations such as Kiribati, Marshall Islands and Tuvalu where all their islands have extremely low elevation, the very real possibility exists that citizens of these states may soon be displaced. Marcus Stephen (2011), the former president of Nauru, warned that there is a very real possibility that 'the low-lying nations of Tuvalu, Kiribati and the Marshall Islands may vanish entirely within our grandchildren's lifetimes'. In addition to rising sea levels, climate change brings about the threat of an increase in the frequency and severity of extreme weather conditions (Banholzer, Kossin, \& Donner, 2014). Such extremes would mean prolonged droughts or wet seasons, and a potential increase in the severity and frequency of hurricanes and cyclones (Anderson \& Bausch, 2006). In the Pacific context, this would mean the potential prolonging of the 'cyclone season' meaning cyclones would occur more frequently and with greater intensity (The World Bank, 2013).

Climate change has thus become a crucial issue that Pacific individuals, groups, organisations and states are striving to cope with. However, climate change is not a local problem that can easily be solved. Human induced climate change has been scientifically proven to be caused by industrialisation and a rapid rise in carbon emissions that has occurred around the globe since the time of the industrial revolution. Pacific Island nations number among the lowest carbon emitters in the world. However, they are on the frontline of experiencing 
the detrimental impacts of climate change (Wéry, 2013).

International cooperation and consensus is thus required to deal with the issue of climate change and how its impacts can be curbed. In order for the Pacific to lobby at international levels, massive resources are needed to educate, inform and foster the participation of citizens from all walks of life. Given the fragile economic structures that typify Pacific economies, ICT tools have huge potential to become a cost effective avenue for climate activism. ICT tools have become prominent in informing citizens and encouraging them to participate in climate change related activism.

\section{The media landscape in the Pacific}

Apart from being geographically diverse, media and communication networks are also heterogeneous (Papoutsaki \& Harris, 2008; Papoutsaki, McManus, \& Matbob, 2011). Various researchers reveal these diverse forms of media and communication play a crucial role in socio-economic and political change in the region (Harris, 2014; Robie, 2014b). Radio is the most effective and farreaching coverage in the region while television maintains viewership mostly in urban centres. Print media has undergone major changes with the advent of ICT revolution, with many newspapers now accessible online (Tacchi et al., 2013). The ICT revolution that the region is undergoing is having an impact on the media and communication landscape, with many people now accessing radio via mobile phones (Cave, 2012; Intermedia Europe, 2012).

\section{Pacific ICTs, journalism training and climate change online education}

A range of professional bodies provide climate information and engagement tools online. This wide range of bodies can cater to different audiences with tailored, meaningful climate engagement information. The growth of new media has provided ways for established institutions, as well as grassroots organisations, to engage individuals in more personally meaningful way. (O’Neill \& Boykoff, 2012)

Pacific leaders have cited climate change as being the greatest threat that the region faces currently. The former Secretary-General of the Pacific Islands Forum, Tuiloma Slade, has likened the situation to the Pacific Ocean being, 'under siege' (Mateus, 2014). The vast majority of the scientific community agree that climate change is occurring, and that it is human induced (Maibach, Myers, \& Leiserowitz, 2014). However, for the Pacific region, there is still a lack of awareness and education at the grassroots level on the impacts of climate change (Harris, 2014). In such environments, journalists play a pivotal role. However, as Harris (2014) notes, journalists have recognised that more training is needed in order to improve on climate change reporting to the general public. 
Journalists around the Pacific region have thus been engaged in various training aimed to help them leverage ICTs for the purpose of climate change reporting. For instance, in 2013, 11 days of training with journalists from all around the Pacific region was conducted by Deutsche Welle. Participants stated that such training was aimed at 'helping journalists and people like myself to provide information on climate change and disaster risk reduction using multimedia tools'. Another participant from Samoa, in highlighting the importance of the training, alluded to how the internet played an increasingly important role for news providers, as people tended to rely on platforms such as Facebook to get their information (NAB, 2013). Additionally, as recently as March 2017, training relating to climate change reporting was carried out in Vanuatu.

In addition to such training, ICTs have been leveraged to provide Pacific Islanders with the means to learn more on climate change. With only one major regional university that caters for much of the Pacific region, educating citizens on the intricacies of climate change has posed a challenge. The development of ICT technology has led to new educational delivery systems. One such example is the 'Massive Open Online Course' (MOOC). This refers to an online course that has unlimited participation and allows free and open access via the internet. ICT developments in text, audio, and visual communication enable real time video conferencing between citizens in various Pacific Island countries. Through online forums, and resource sharing sites, citizens can access a multitude of information in seconds. MOOCs seek to amalgamate these features into a platform that facilitates interactive learning for an unlimited number of citizens free of charge. One such example is the MOOC platform designed by the Pacific Centre for Environment and Sustainable Development (PACE-SD) based at the University of the South Pacific. The following paragraph provides discussion on this MOOC system and how it uses ICT tools to educate and disseminate information to citizens.

PACE-SD, in collaboration with funding partners, has designed a MOOC

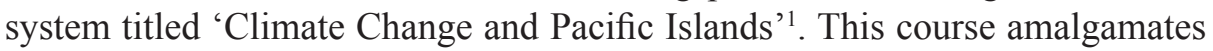
a variety of ICT platforms that have enabled online community interactions between students and teaching staff. In the spirit of a Habermasean public sphere (Habermas, 2006), an online platform has been created where members of the public interested in climate change can access data and carry out dialogue and debate in an unrestricted fashion. The platforms employed are described below:

1. Use of audio visual material

On the course site, audiovisual materials such as videos and images are provided to give students a thorough grounding on the issues centred upon climate change in the Pacific. These materials include video recorded lectures as well as hyperlinks to other educational resources that students can visit to further their knowledge. 
2. Use of social media teaching forums

The course is not limited to being simply a provider of information through audiovisual tools. The MOOC platform is linked with social media platforms where students and the teaching team can confer and debate on issues related to climate change and the educational material provided by the course. The course material is also linked to Twitter and 'a Facebook group'2. On these platforms, students and teaching staff interact and discuss climate change issues. Thus, a public sphere comprised of students from around the Pacific has been created.

Overall, the examples mentioned above describe how ICT tools can foster dialogue and participation on issues relating to climate change.

\section{ICTs and citizen journalism in the Pacific}

As access to ICTs increase around the Pacific, individuals and groups have greater opportunities to become active content creators. These opportunities permit them to share their accounts of events that impact them. In her review of Stuart Allen's book on citizen witnessing, Rupar (2013), noted how in this day and age, "people in extraordinary situations do what journalists do: collect, process and disseminate information by tweeting, blogging and posting texts, images and video recordings'.

ICTs are now facilitating a growth in 'citizen journalism'. Singh (2017) notes how in Melanesia, citizen journalism is now picking up pace. ICT platforms such as social media are now being employed as a means to report on human rights issues in media repressive countries such as West Papua (Robie, 2017; Titifanue et al., 2016). The potential power of these tools is formidable, and as Macleod (2016) noted, social media has started influencing the opinion of heads of state, with Pacific leaders such as Gordon Darcy Lilo, former prime minister of Solomon Islands, and Peter O'Neill of Papua New Guinea acknowledging social media's role in highlighting human rights issues in West Papua.

Various groups are now using ICT platforms to foster their climate activism. Examples can be seen in the use of tools such as Snapchat to garner international interest in climate activism. This is evidenced by 350.org activist Fenton Lutunatabua who stated in an interview that:

'Snapchat is real life, showing how things look without a filter,' he said. .... The shorter the video, the more likely it will be viewed. 'People are way more likely to watch a 10 -second snap. And it's from your point of view, you can show the world what's really happening.' (Cronin, 2016)

With regard to climate change reporting, it is also noted that grassroots reporting of environmental events can fill in a gap in mass media reporting and knowledge. As Patel (2006) notes, journalists in the science and environmental 
fields are expected to 'know too much ... [and] to grasp, communicate and synthesise scientific, political and economic issues'. Citizen reporting adds the invaluable dimension of providing the outlook of people at the grassroots level. Through such means, environmental issues can be reported more holistically, and in a manner that precisely illustrates how people at the grassroots are impacted. As Robie (2010), noted, 'participatory journalism involves citizens using the internet to play a role in collecting, reporting, analysing and disseminating news and information'.

Apart from being a means to report, educate, and inform on climate change issues, ICTs have also been tapped into as a means to further activism. The usage of ICTs for climate change activism is discussed in the following sections.

\section{ICTs and climate change activism}

In activism and advocacy work, dissemination of information and the generation of discussion and participation in issues of interest have traditionally been done by the mainstream media, non-government organisations (NGOs) and lobby groups (Tarai, Finau, Kant, \& Titifanue, 2015). Platforms such as television, the radio and print media have long been the means for informing citizens and enabling discussion and participation. However, the means of diffusing information and fostering activism are not set in stone. They are constantly evolving. ICT tools are the latest tools available with the efficiency they provide in communication and the dissemination of information.

In the Pacific context, the region is geographically isolated and in the past communication between Pacific islands and with the rest of the world was difficult. ICTs offer the means to greatly facilitate communication and offset the past challenges the Pacific faced due to its geographic isolation (Cave, 2012). In the Pacific, individuals, groups and organisations all around the region are concerned with, and striving to address, the issue of climate change. However, given that climate change is an issue that needs to be addressed at a global level, it is vital that these various individuals and organisations work cohesively and in coordination. A means of coordinating the activities of these various interest groups and fostering the sharing of information, debate and cooperation is needed. ICTs though relatively new to the region are being harnessed to articulate the climate change narratives of the region.

As technology develops, new means of outreach and advocacy have sprung up in an attempt to tap into the activism tools offered by new technologies. This is illustrated by how, in 1997, the International Campaign to Ban Landmines (ICBL) widely utilised the internet and computer mediated communication to gain international momentum and foster the signing of a treaty to ban landmines (Williams, Goose, \& Wareham, 2008). Over a decade later in 2010, the International Red Cross was tapping into cellular phone text messages to encourage people to 
make donations towards earthquake relief in Haiti. In four days, these outreach efforts had assisted in raising US\$7 million (Rotman et al., 2011).

ICTs and their platforms have thus become a key instrument in climate change activism. Tools such as video conferencing, emails, e-Learning platforms, and social media have been incorporated by activists, organisations and states as advocacy tools. Through ICTs, an online public sphere has developed in the Pacific whereby citizens can confer and debate in unrestricted fashion about matters of general interest that are pertinent to the issue of climate change. Not only have ICTs been used to foster debate and discussion, they have also been used to help encourage and organise various advocacy activities. The next sections of this article delve into how ICTs and their affiliated platforms have been used in the Pacific for the purpose of disseminating information and fostering advocacy and activism.

Carter $(2016$, p. 206; 216) states that the continuous international meetings in relation to climate change have allowed for the transformation of climate diplomacy. International associations that Pacific states are part of have recognised the need to communicate their messages and policy positions to the public. With the proliferation of ICTs, state and non-state actors, and interest groups have become ever more connected and become more aware and attuned to the progress of these international meetings. These international state based associations (such as PSIDS, G77, Least Developed Countries (LDCs), Alliance of Small Island States (AOSIS), Coalition of Rainforest Nations, Climate Vulnerable Groups, Coalition of Atoll Nations on the issue of Climate Change (CANCC)) have started utilising ICT-enabled social networking sites to communicate messages rather than relying on traditional media. This has opened up avenues for more innovative forms of climate change diplomacy and making possible dialogue to a more wider, global audience (Carter, 2016, p. 216). This sentiment was highlighted by Professor Elisabeth Holland who stated;

Social media is a powerful tool and will help highlight to the world, what the Pacific is fighting for in Paris and how that will affect the smallest communities in our large ocean states. (Pacific Island Forum, 2015)

Social media platforms such as Facebook and Viber are greatly conducive to communication, and have been adopted by climate activists for communication purposes. Facebook and Viber offer instant messaging as well as audio and video calling features. Such features only need access to the internet in order to function. With the burgeoning penetration of ICTs and technological advances, access to the internet has greatly improved and become more affordable. Through this connectivity, information is shared amongst individuals before being disseminated to a wider audience. This is illustrated by the planning 
of a climate justice protest that took place on the 23 September 2015 in front of the Australian High Commission in Fiji. Interviews with participants revealed that instant messaging services were used to rapidly spread word of the planned event amongst interested individuals. The communique encouraged interested individuals and groups to share the message broadly on their own networks and to make use of social media hashtags to 'please amplify everyone else's photos, quotes, rallies at your websites, FB pages, Instagram, etc.' (COP21 Urgent Action Hub, 2015).

While effective as a means of communication dialogue and information sharing among activists, social media has not simply been limited to being a communications tool. Individuals and groups have devised tactics that have allowed them to social media, for the purpose of coordinating and promoting climate activist events. As individuals and groups strive to gain momentum in their advocacy and activism, several social media features have come to play a role in facilitating this. Most notably these features include multimedia content, event invitations and the hashtag tool.

Multimedia content such as images, videos, and artwork, serve as a powerful means to capture the attention of the social media audience. Robie (2010) noted how iconic media images have been used to highlight the plights Pacific Islanders face with the advent of climate change. Social media platforms (such as Facebook groups and/or pages) easily facilitate the creation and sharing of such multimedia. This serves to garner the interest of people and raise the political and policy profile of issues. Furthermore, the interactive tools offered on social media platforms allow users to carry out discussions and debate around the issues related to the multimedia content posted.

Event invitations allow users to add on a description of an event and link this event to online mapping applications for the purpose of providing directions to the location of the event. The significance of this feature is that once the event is created, individuals can access information on the event and forward invitations to their own personal networks, resulting in a snowball effect. The event platform also allows the posting of multimedia content related to the event. This enables users who access the event to know not only when and where the event is taking place, but also to derive information relating to all issues surrounding the event.

Lastly, Hashtags, which refers to the prefixing of a phrase or slogan with a hashtag (\#) symbol, and the creation of a hyperlink that, when clicked on, will show users a complete list of social media content that contain the hashtag. In the context of online activism, these hashtags are used to ensure cohesion and allow ease of access to social media activities carried out by climate activists. Using hashtags mean that users are able, at the click of a button to view all social media content relating to a particular climate change theme. 
The use of these features is prompting a resurgence of grassroots/bottom-up regionalism. While regionalism is typically characterised by interactions between various state actors (Fry \& Tarte, 2016), there are instances when individuals and groups at the grassroots can carry out a bottom-up push that places pressure on regional issues of general interest (George, 2011). Examples of these include anti-nuclear movements in the Pacific, whereby, from the 1960s to the mid-1990s, various western powers such as the USA and France carried out nuclear testing in the Pacific. Over time however, regional solidarity seemed to take a hiatus at the grassroots level and became simply something that decision makers and academics concerned themselves with. In recent times however, through digital interconnectivity, there has been resurgence in grassroots interest on key issues that have captivated the public imagination. This can be evidenced by the surge in interest and outrage around the Pacific over human rights issues taking place in West Papua (Titifanue et al., 2016).

\section{Climate change and bottom-up regionalism}

Being an international issue that is caused and exacerbated by carbon emitting activities in industrialised countries, the countries that will feel the brunt of climate change are typically those who have contributed little towards causing it (Duong, 2010). International cooperation, consensus, and action in addressing climate change is thus crucial. Pacific leaders such as former Kiribati president, Anote Tong, and more recently, Fiji Prime Minister Voreqe Bainimarama have thus been issuing calls and challenges to the global community on the need for unified action on climate change. Furthermore, in December 2015, Pacific leaders gathered at the 21st Conference of Parties in Paris (COP21) with the aim and intent of representing the plight of their respective countries in the hopes of achieving a climate treaty that could help Pacific islands 'survive'.

These climate negotiations and stances have followed the conventional regionalism definition, with negotiations occurring between state representatives at global and regional platforms. However, grassroots activism and advocacy have acted to fuel much debate and discussion prior to, during, and after COP21. With climate change projected to affect the entire the Pacific in terms of rising sea levels (Adger et al., 2003), increased spread of diseases (Potter, 2008), and degraded food security (Barnett, 2011), individuals and groups around the Pacific have become heavily invested in the issue of climate change in a manner that transcends political and ethnic borders.

Bottom-up regionalism in the context of climate change activism from civil society is evidenced by 350.org's Pacific-wide 'Warrior Day of Action' global campaign with the message 'We are not drowning. We are fighting'. (350.ORG, 2013). This campaign mobilised Pacific Islanders at prominent locations 'to perform their unique war challenges, songs, and dances'. The idea behind this 
campaign was to change the global narrative from a dystopian narrative that Pacific islands are drowning from sea-level rise associated with climate change to one where for Pacific Islanders (and the global community), 'it's not yet time to give up on the Islands':

So it's time to change the global narrative of the Pacific Islands-from drowning and victimisation, to building the power to fight the fossil fuel industry, and climate change. And as the global climate movement, it's our job to never give up on them, and to fight every step of the way with them. (350.ORG, 2013)

'We are not drowning, we are fighting' is an empowering call to action of climate advocacy championed by $35.0 r g$. The traditional attire adorned by Pacific climate activists draws on their 'oceanic identity', working a historical image of ancestral responsibility to their oceans, islands, and most importantly, their homes. The warrior is seen as a fierce protector of his chief and of his people. In essence, his is the burden of calling on and challenging neighbourly rivals or warring adversaries. Now the climate warrior is calling on and challenging the world, highlighting climate change, far beyond his typical foes of warring tribes.

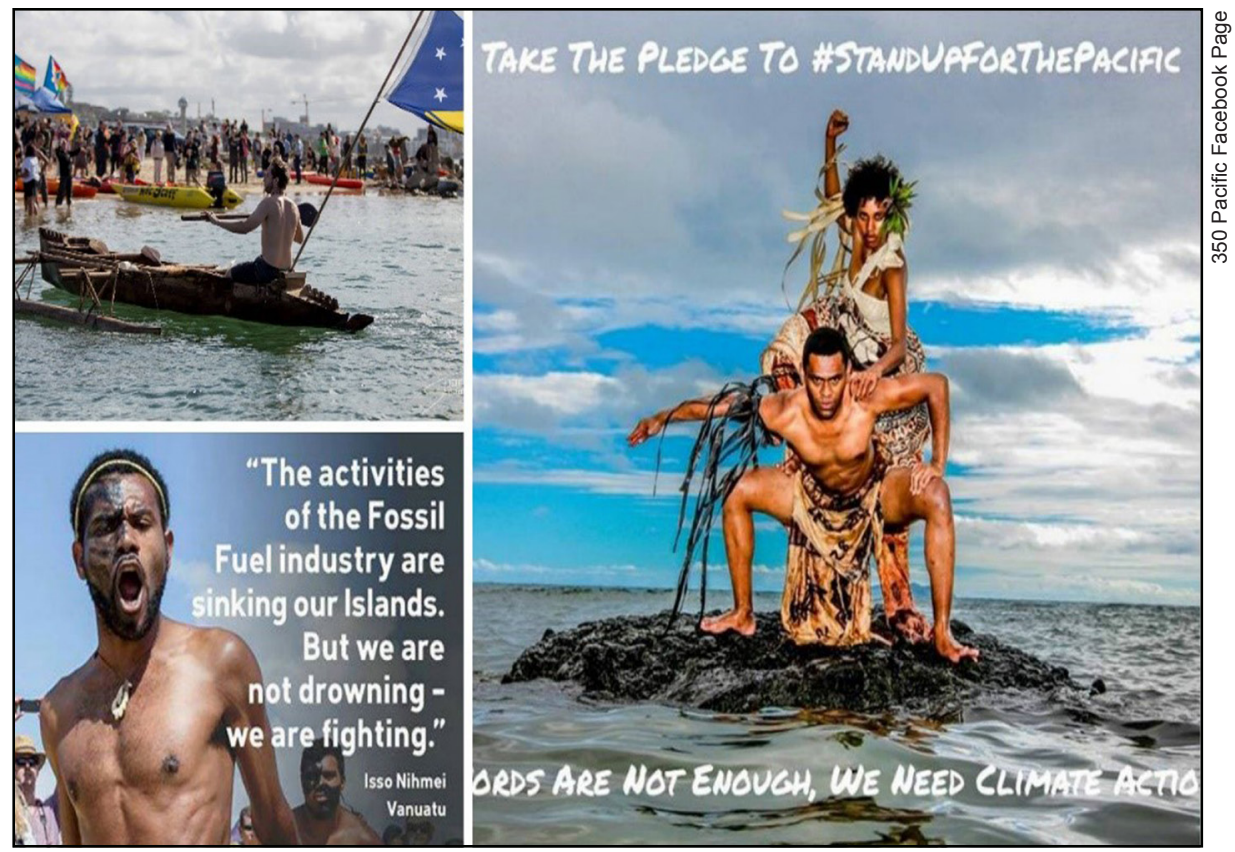

Figure 1: Collage of climate warriors. 
The Pacific communications coordinator of 350.org argues that:

We are dignified warriors, who stand by these principles: A warrior is resilient .... not aggressive or violent, but .... Assertive .... serves to protect their community, culture, land and ocean .... always learning .... responds to the needs of those around them and of the greater good .... non-violently stands their ground against an adversary, against injustice and against oppression .... respectfully embodies their local culture and traditions .... is accountable for their actions and words .... serves those who cannot fight for themselves - future generations, animals and plants, environments. (Lutunatabua, 2014)

The array of tools provided by digital technologies has facilitated increased cross border interaction and advocacy. This is apparent in the tools and campaigns assessed in this research which demonstrate the multitude of individuals and groups across the Pacific that regularly use digital technologies to share information, communicate, and organise. Participants at COP21 alluded to how they used digital technologies to strengthen their voice at the bargaining table. As one focus group interviewee stated:

...Most at COP are opposition - most that have the Pacific marginalised we try to get some leverage-For some of them we know that they have their mission pages on twitter ... we visit these accounts. For examplePhilippines - we mass tweet their members that are part of the COP21, .... In addition to this we also have members; friends and young people on that end [in Pacific region] that are able to make noise. This way we triple or maximise the noise .... We're coming in from more angles. (Focus group interviewee, 2016)

Through digital technologies, greater interconnectivity has been fostered amongst individuals and groups. Content analysis of climate change related social media pages reveal that there is a wide cross section of individuals partaking in the sharing of information and dialogue. Figure 2 shows how activists and campaigns have enlisted the support of Pacific sports celebrities. The campaign below used the slogan 'Enough is Enough' and the unifying hashtag: \#STANDUPFORTHEPACIFIC. As earlier noted, Robie (2010) has shown how iconic media environmental images of Pacific Islanders were used to communicate the plight of Pacific Islanders caused by climate change. Robie further goes on to make the point that; "the Pacific is unwilling to simply be cast aside as stateless "climate refugees", as portrayed by the Western media'. This is noteworthy, as in a further evolution in the adaptation of digital technologies, in recent social media campaigns Pacific Islanders are not depicted as climate change victims but as 'warriors' fighting climate change. These campaigns seek 


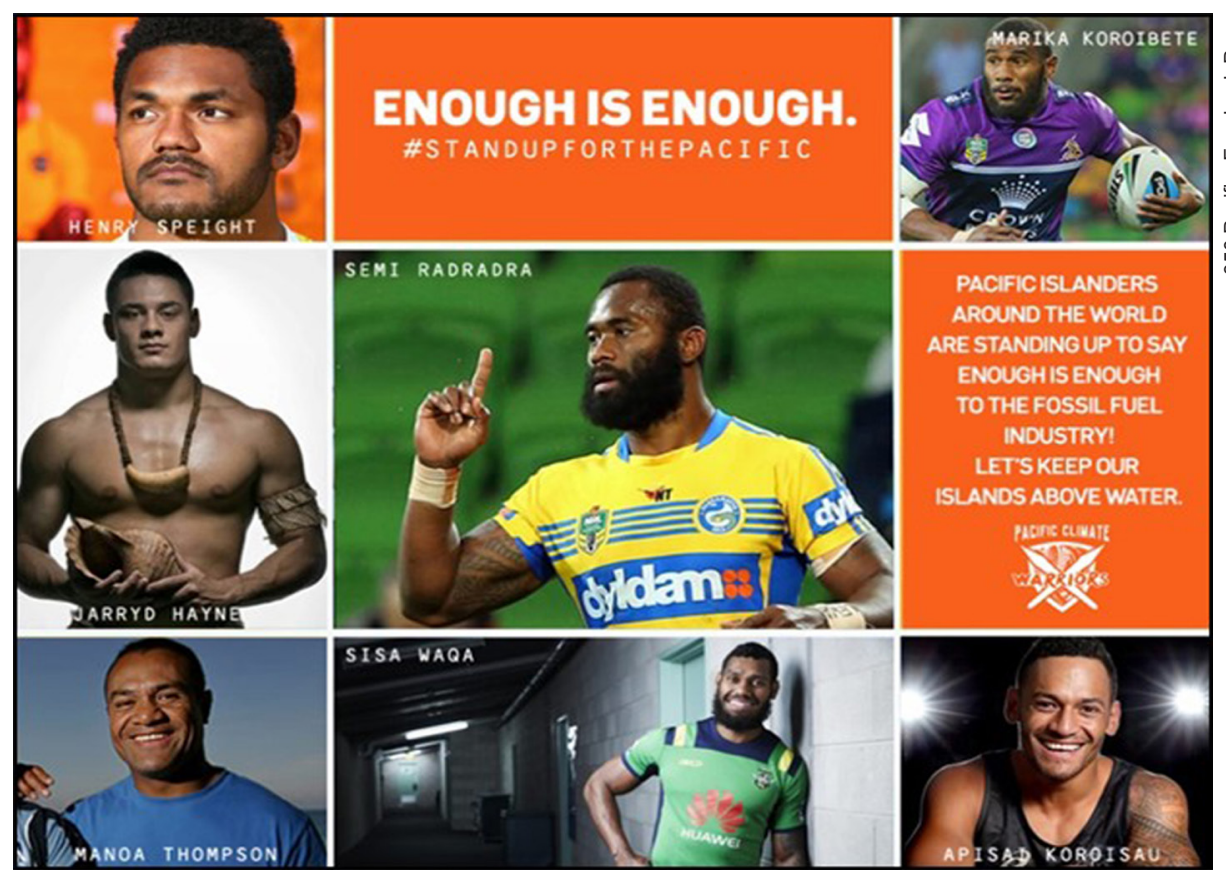

Figure 2: Pacific Island sports personalities rallying around \#STANDUPFORTHEPACIFIC hashtag.

to engender a unified Pacific identity showing solidarity in the Pacific on the issue of climate change.

\section{Conclusion}

With increases in ICT penetration levels, the diffusion of information around the Pacific is taking place more rapidly than ever. The decentralised nature of ICTs and their ability to reach large numbers of people in a short time has enabled increased education of citizens in the matter of climate change. Apart from being a means of educating people and disseminating information, ICT related platforms such as social media have proven to be a useful and effective means of fostering debate on climate advocacy and translating this debate into protests and marches. ICTs have contributed to the creation of online communities where citizen from various walks of life disseminate information and debate on the issue of climate change in an unrestricted fashion.

ICT tools offer ordinary citizens the potential to become active content creators and allow their narratives to be heard. The potential ramifications of citizens having the power to actively create and disseminate content on a regional and global scale are a phenomenon that deserves further attention and research. ICT platforms offer a variety of tools that have been tapped into by activists and advocates alike for the purpose of mainstreaming their messages. With a global 
outreach that is continuously growing, ICTs remain a potent tool for activism.

The apparent revival of bottom-up grassroots regionalism is an intriguing notion that this research has explored. It is noted that Pacific Islanders at the grassroots have historically rallied together over issues that profoundly impact the Pacific. While the Pacific region faces a number of issues, nuclear testing, and the current issues of West Papuan human rights, and climate change have captivated the public imagination to a greater extent. This research posits that Pacific grassroots regionalism is brought about when issues arise that can captivate the public imagination on the basis of their impact in terms of livelihoods, morality, and existence. This is evidenced by the waning of grassroots cohesiveness in the post-nuclear testing era, and its advent with the issues of West Papuan human rights, and climate change.

It must be noted, that while ICT penetration rates are burgeoning in the Pacific, this remains a predominantly urban phenomenon. Urban populations in the Pacific are the best placed to take advantage of new ICT resources. This is changing as ICT technologies increasingly become more affordable and ubiquitous. However, at this stage in time, mass media tools and in particular radio stations remain the most widespread and effective means of communicating information to the greatest number of people around the Pacific.

This research aims to contribute to the limited literature that exists on online activism in the Pacific region. Future researchers delving into this field would benefit from carrying out more comprehensive interviews with a larger crosssection of activists and organisations. Employing online analytics tools would also enable future researchers to carry out a more systematic analysis on the efficaciousness of online climate change activism. Future research projects would benefit from assessing the impact of how increasing access to ICTs in rural areas influences citizen discourse on matters of general interest.

\section{Notes}

1. The link to the MOOC site: www.uspmoocpaccc.org

2. Links to the twitter and Facebook forums used can be found here:

Twitter: @uspmoocpaccc

Facebook: www.facebook.com/groups/uspmoocpaccc/?ref=ts\&fref=ts

\section{References}

350 Pacific. (2017). 350 Pacific Facebook Page. Retrieved 18 February 2017, from www.facebook.com/350Pacific/?ref=page internal

350.ORG. (2013). We are not drowning. We are fighting. 350.org. Retrieved 20 February 2017, from http://350pacific.org/we-are-not-drowning-we-are-fighting/

Adger, W. N., Huq, S., Brown, K., Conway, D., \& Hulme, M. (2003). Adaptation to climate change in the developing world. Progress in development studies, 3(3), 179-195. 
Anderson, J., \& Bausch, C. (2006). Climate change and natural disasters: Scientific evidence of a possible relation between recent natural disasters and climate change. Policy Department Economic and Scientific Policy, 02(a).

Banholzer, S., Kossin, J., \& Donner, S. (2014). The impact of climate change on natural disasters. In Z. Zommers \& A. Singh (Eds.), Reducing disaster: Early warning systems for climate change (pp. 21-49): Springer.

Barnett, J. (2011). Dangerous climate change in the Pacific Islands: food production and food security. Regional Environmental Change, 11, 229-237. doi: 10.1007/s10113010-0160-2

Beaumont, P., Braithwaite, R., Drewery, D., Gornitz, V., Grove, J., Haeberli, W., . . . Lorius, C. (2014). Sea level rise.

Carter, G. (2016). Establishing a Pacific voice in the climate change negotiations. In G. Fry \& S. Tarte (Eds.), The New Pacific Diplomacy (pp. 205-220). ACT, Australia: ANU Press.

Cave, D. (2012). Digital islands: How the Pacific's ICT revolution is transforming the region. Retrieved 9 June 2015, from www.lowyinstitute.org/publications/digitalislands-how-pacifics-ict-revolution-transforming-region

COP21 Urgent Action Hub (2015). [Call for Action].

Cronin, M. (2016, May 3). Fighting climate change with Snapchat? Meet the Pacific Islander trying it out [Online]. Grist. Retrieved from http://grist.org/climate-energy/ fighting-climate-change-with-snapchat-meet-the-pacific-islander-trying-it-out/

Duong, T. T. (2010). When islands drown: The plight of climate change refugees and recourse to international human rights law. University of Pennsylvania Journal of International Law, 31(4), 1239.

Finau, G., Prasad, A., Kant, R., Tarai, J. V., Logan, S., \& Cox, J. (2014). Social media and e-democracy in Fiji, Solomon Islands and Vanuatu. Paper presented at the Americas Conference on Information Systems.

Fry, G., \& Tarte, S. (2016). The 'new Pacific diplomacy': An introduction. In G. Fry \& S. Tarte (Eds.), The new Pacific diplomacy (pp. 3-19). ACT, Australia: ANU Press.

George, N. (2011). Pacific Women Building Peace: A Regional Perspective. The Contemporary Pacific, 23(1), 37-71.

Habermas, J. (2006). Political communication in media society: Does democracy still enjoy an epistemic dimension? The impact of normative theory on empirical research. Communication Theory, 16, 411-426.

Hall, E. (2015). Kiribati president pleas for aid as island country submerges. The World Today. Retrieved 21 August 2015, from www.abc.net.au/worldtoday/content/2015/ s4292728.htm

Harris, U. S. (2014). Communicating climate change in the Pacific using a bottom-up approach. Pacific Journalism Review, 20(2), 77.

Intermedia Europe (Producer). (2012, June). Citizens access to information in Papua New Guinea: Citizen survey. ABC International Development. Retrieved from www.abcinternationaldevelopment.net.au/wp-content/uploads/2012/09/ABC-PNG-Report.pdf.

Keener, V., Marra, J., Finucane, M., Spooner, D., \& Smith, M. (2013). Climate change and Pacific islands: Indicators and impacts: Report for the 2012 Pacific islands regional climate assessment. Washington, DC: Pacific Islands Regional Climate Assessment.

Lutunatabua, F. (2014). Pacific warriors declare: 'We are not drowning, we are fighting'. The Huffington Post. Retrieved 18 February 2017, from www.huffingtonpost.com/ fenton-lutunatabua/pacific-warriors-declare-_b_4598552.html

Macleod, J. (2016). Citizen media and civil resistance in West Papua. Pacific Journalism Review, 22(1), 38-51. 
Maibach, E., Myers, T., \& Leiserowitz, A. (2014). Climate scientists need to set the record straight: There is a scientific consensus that human-caused climate change is happening. Earth's Future, 2(5), 295-298.

Mateus, S. D. (2014). Climate change: The 'greatest threat' to the peoples of the Pacific. Deutsche Welle. Retrieved 23 May 2017, from http://p.dw.com/p/1CmNP

NAB. (2013). Pacific journalists into climate change training. Retrieved 23 May 2017, from www.nab.vu/pacific-journalists-climate-change-training

O'Neill, S., \& Boykoff, M. (2012). The role of new media in engaging the public with climate change. In L. Whitmarsh, I. Lorenzoni \& S. O’Neill (Eds.), Engaging the public with climate change: Behaviour change and communication (pp. 233-251): Routledge.

Pacific Island Forum. (2015). Campaign to amplify Pacific voice on climate change. Retrieved 6 February 2017, from www.scoop.co.nz/stories/WO1511/S00013/ campaign-to-amplify-pacific-voice-on-climate-change.htm

Papoutsaki, E., \& Harris, U. (2008). Pacific islands communication issues: Local issues, regional perspectives. Singapore; Suva; Auckland: AMIC: USP; PMC (AUT).

Papoutsaki, E., McManus, M., \& Matbob, P. (2011). Communication, culture and society in PNG: You tok tok long housat? Auckland: Pacific Media Centre; DWU Press.

Patel, S. (2006). 'Islands of understanding': Environmental journalism in the South Pacific. Pacific Journalism Review, 12(2), 148-153.

Potter, S. (2008). The sting of climate change: Malaria and dengue fever in maritime southeast Asia and the Pacific islands. Lowy Institute Policy Brief.

Robie, D. (2010). Iconic media environmental images of Oceania: Challenging corporate news for solutions. Dreadlocks: Oceans, Islands and Skies, 6/7, 22-47.

Robie, D. (2014a). 'Carbon colonialism': Pacific environmental risk, media credibility and a deliberative perspective. Pacific Journalism Review, 20(2), 59-76.

Robie, D. (2014b). Don't spoil my beautiful face: Media, mayhem and human rights in the Pacific: Auckland: Little Island Press.

Robie, D. (2017). Tanah Papua: Asia-Pacific news blind spots and citizen media: From the 'act of free choice' betrayal to a social media revolution. Otago Foreign Policy School Monograph (forthcoming).

Rotman, D., Vieweg, S., Yardi, S., Chi, E. H., Preece, J., Shneiderman, B., .. . Glaisyer, T. (2011). From slacktivism to activism: Participatory culture in the age of social media. CHI'11 Extended Abstracts on Human Factors in Computing Systems, May, 819-822.

Rupar, V. (2013). A fresh take on journalism authority. Pacific Journalism Review, 19(2), 243-245.

Singh, S. (2017). State of the media review in four Melanesian countries-Fiji, Papua New Guinea, Solomon Islands and Vanuatu-in 2015. SSGM Discussion Paper, 2017(1).

Stephen, M. (2011). On Nauru, a sinking feeling. The New York Times, The Opinion Pages. Retrieved 22 August 2015, from www.nytimes.com/2011/07/19/opinion/19stephen. html? r=0

Tacchi, J., Horst, H., Papoutsaki, E., Thomas, V., \& Eggins, J. (2013). PACMAS: Regional State of Media and Communication Report. Melbourne: PACMAS/ABC International Development.

Tarai, J., Finau, G., Kant, R., \& Titifanue, J. (2015). Political social media campaigning in Fiji's 2014 elections. The Journal of Pacific Studies, 35(2), 89-114.

The World Bank. (2013). Acting on climate change and disaster risk for the Pacific, Washington, DC: World Bank.

Titifanue, J., Tarai, J., Kant, R., \& Finau, G. (2016). From social networking to activism: The role of social media in the free West Papua campaign. Pacific Studies, 39(3), 255-281. 
Wéry, C. (2013). Pacific islands look for model to combat changes due to global warming. The Guardian. Retrieved 22 August 2015, from www.theguardian.com/environment/2013/may/07/pacific-islands-global-warming-climate

Williams, J., Goose, S. D., \& Wareham, M. (2008). Banning landmines: Disarmament, citizen diplomacy, and human security: New York, NY: Rowman \& Littlefield Publishers.

Jason Titifanue is a teaching assistant at the University of the South Pacific (USP), Fiji, a research associate of the Development Leadership Programme (DLP), and an honorary research associate with the Institute of Human Security and Social Change, La Trobe University.

wesleytitifanue@gmail.com

Romitesh Kant is a research associate in the $D L P$, and an honorary research associate with the Institute of Human Security and Social Change, La Trobe University.

Glen Finau is an assistant lecturer in the School of Accounting and Finance, Faculty of Business and Economics at USP, and a PhD scholar at the Australian Defence Force Academy, University of New South Wales. He is also a research associate with the DLP and an honorary research associate with the Institute of Human Security and Social Change, La Trobe University.

Jope Tarai is a teaching assistant at USP and a research associate with the DLP and an honorary research associate with the Institute of Human Security and Social Change, La Trobe University. 